\title{
Layanan Informasi melalui Voluntary Counseling and Testing pada Kelompok Resiko Tinggi (Analisis Bimbingan Konseling Islam)
}

\author{
Anis Lud Fiana \\ Pascasarjana Universitas Negeri Semarang, Jawa Tengah, Indonesia \\ anislud22@students.unnes.ac.id
}

\section{Amrizarois Ismail}

Universitas Katolik Soegijapranata Semarang, Jawa Tengah, Indonesia

amrizarois@unika.ac.id

\author{
Sri Maullasari \\ Pascasarjana Universitas Negeri Semarang, Jawa Tengah, Indonesia \\ maullasari174@students.unnes.ac.id
}

Isa Aulia Rohman

Pascasarjana Universitas Negeri Semarang, Jawa Tengah, Indonesia isaauliaro@students.unnes.ac.id

\begin{abstract}
Abstrak
Layanan informasi memungkinkan konseli menerima dan memahami berbagai informasi di berbagai bidang seperti pendidikan, sosial, kesehatan dan lainnya. Program konseling dalam layanan informasi Voluntary Counselling and Testing (VCT) bertujuan untuk memberikan pengetahuan tentang menjaga kesehatan untuk menekan penyebaran HIV/AIDS. Kasus tertular virus HIV/AIDS dapat dialami oleh siapa saja, salah satunya yaitu kelompok berisiko tinggi men sex men (MSM), transgender (TG) dan people who inject drugs (PWID). Penelitian ini bertujuan untuk memberikan analisis implementasi layanan informasi melalui VCT dalam pencegahan penularan HIV/AIDS pada kelompok beresiko tinggi. Desain penelitian ini menggunakan metode kualitatif deskriptif dengan mengambil sampel dari kelompok dampingan di PKBI Kota Semarang. Layanan informasi dalam VCT berisi tentang pengetahuan
\end{abstract}


penularan dan pencegahan HIV/AIDS. Pada penelitian ini menunjukkan cukup efektifnya layanan informasi yang diberikan oleh petugas pada proses VCT dalam pencegahan penularan HIV/AIDS kelompok berisiko tinggi, untuk kemudian dianalisis dengan model bimbingan konseling Islam.

Kata kunci: Layanan Informasi, Voluntary Counselling and Testing, HIV AIDS, Kelompok risiko tinggi

\begin{abstract}
Information Services through Voluntary Counseling and Testingfor High-Risk Groups (Islamic Counseling Guidance Analysis). Information services allow clients to receive and understand various information in various fields such as education, social, health, and others. The counseling program in the information service Voluntary Counseling and Testing (VCT) aims to provide knowledge about maintaining health to reduce the spread of HIV/AIDS. Anyone can experience cases of contracting the HIV/AIDS virus, one of which is the high-risk group for sex men (MSM), transgender (TG), and people who inject drugs (PWID). This study aims to provide an analysis of the implementation of information services through VCT in the prevention of HIV/AIDS transmission in high-risk groups. The design of this study used a descriptive qualitative method by taking samples from assisted groups in PKBI Semarang City. Information services in VCT contain the knowledge of HIV/AIDS transmission and prevention. This study shows the effectiveness of information services provided by officers in the VCT process in preventing transmission of HIV/AIDS in the high-risk group to be analyzed using the Islamic counseling guidance model.
\end{abstract}

Keywords: Information Services, Voluntary Counseling, and Testing, HIV AIDS, High-Risk Groups

\title{
A. Pendahuluan
}

Pekembangan kasus HIV/AIDS di dunia telah menjadi masalah global termasuk di Indonesia. HIV atau Human Immunodeficiency Virus adalah virus yang menyerang sel darah putih sehingga dapat merusak sistem kekebalan tubuh manusia yang pada akhirnya tidak dapat bertahan dari gangguan penyakit walaupun yang sangat ringan sekalipun. Pertarungan antara ODHA dengan Human Immunodeficiency Virus (HIV) yang bersarang dalam tubuhnya adalah pertarungan 
melawan waktu. Virus HIV jika dibiarkan tanpa pengobatan maka akan menyebabkan Acquired Immunodeficiency Syndrome (AIDS). Virus HIV tetap ada seumur hidup, walupun sudah menjalani pengobatan. Dalam jangka waktu sekitar 10 sampai 12 tahun, HIV dapat menyebabkan AIDS (Acquired Immunodeficiency Syndrome). HIV sendiri adalah virus yang menyerang sistem kekebalan tubuh sehingga tubuh rentan terhadap berbagai penyakit seperti TB, TORCH, dan lain-lain. Sedangkan, AIDS adalah kumpulan penyakit yang disebabkan oleh virus HIV ditandai dengan menurunnya sistem kekebalan tubuh.

Untuk membantu perubahan perilaku sehingga risiko tertular HIV menurun, pemerintah pun membuka sebuah layanan yang disebut Voluntary Counseling and Testing (VCT). Layanan VCT adalah gabungan dari proses konseling dan tes HIV. Keistimewaan layanan VCT ini tidak hanya pada proses konseling saja, melainkan sampai pada proses tes dan pos tes. Selain bertujuan untuk membantu perubahan perilaku, juga guna mencegah penularan HIV, meningkatkan kualitas hidup ODHA, serta untuk sosialisasi dan mempromosikan layanan dini (Retnaningsih, 2016). Konseling dan tes sukarela (VCT) terus memainkan peran penting dalam pencegahan, perawatan, dan pengobatan HIV. Dalam beberapa tahun terakhir, berbagai modalitas VCT telah diterapkan, termasuk tes dan konseling berbasis klinik maupun mobile. Mempelajari status HIV seseorang dan menerima konseling merupakan langkah penting untuk menerima perawatan dan pengobatan terkait HIV, tetapi juga merupakan intervensi penting untuk berpotensi mengubah perilaku berisiko terkait HIV.

VCT menjadi salah satu upaya dalam pendeteksi dini yang dianggap perlu dilakukan untuk mencegah penyebaran HIV/AIDS. Tes ini merupakan suatu pembinaan dua arah atau dialog yang berlangsung tak terputus antara konselor dan kliennya dengan tujuan untuk mencegah penularan HIV, memberikan dukungan moral, informasi, serta dukungan lainnya kepada ODHA, keluarga dan lingkungannya (Satriani, S., Nurhayani, N., \& Balqis, 2016). Sejauh ini tes VCT efektif untuk mengetahui status seseorang tersebut terinfeksi virus atau tidak, sifat 
konseling dan testing secara sukarela membentuk pola sadar berperilaku sehat bagi seluruh masyarakat.

Layanan informasi yang terkandung dalam proses VCT bertujuan untuk pemberian pemahaman kepada individu yang memiliki kepentingan tentang berbagai hal yang diperlukan dalam menjalani tugas atau kegiatan tertentu guna mengarahkaan suatu tujuan atau rencana yang dikehendaki. Pada prinsipnya, VCT dilakukan secara sukarela dan bersifat rahasia. Artinya, dilakukan atas keinginannya sendiri, tanpa paksaan dari pihak lain untuk datang ke penyedia layanan VCT. Selama proses pra dan pasca konseling terjaga kerahasiaannya. Layanan ini menjadi upaya penting dalam pencegahan dan pengendalian HIV/AIDS. Tidak hanya sebatas tahu status seseorang terinfeksi atau tidak, dalam VCT juga ada proses pra konseling dan pasca konseling yang dilakukan. Konselor mengetahui tingkat resiko konseli sebelum melakukan tes dan membangun kesadaran untuk melakukan tes HIV merupakan hal yang dilakukan pada tahap pra konseling. Konselor menyampaikan hasil tes VCT dan memberikan motivasi untuk selalu berperilaku pola hidup sehat VCT pada tahap pasca konseling. VCT juga membantu penanganan setelahnya yakni dalam proses pendampingan seseorang yang terinfeksi virus HIV, usaha dalam pendistribusian obat ARV tepat sasaran dan usaha bersosialisasi pola hidup sehat walaupun pada kelompok yang beresiko tinggi. Kelompok kunci atau kelompok beresiko tinggi yaitu kelompok yang tidak menggunakan pengaman (kondom) dalam behubungan seks dan berganti-ganti pasangan. Pengguna narkoba suntik juga menjadi salah satu kelompok beresiko tertularnya HIV/AIDS (Sumini,. Hadisaputro, 2017). HIV menyebar cepat karena penggunaan jarum suntik yang tidak steril dan bergantian dalam penggunaan.

Kelompok beresiko yang kami maksud cakupannya meliputi men sex men (MSM) atau Gay, Waria, dan Penasun dampingan rujukan tes HIV dari PKBI Kota Semarang. Mereka menjadi populasi kunci dalam kasus persebaran HIV/AIDS karena masih kurangnya kesadaran secara pribadi terkait kesehatan seksual. Pendampingan terhadap kelompok beresiko sangat perlu dalam penyampaian 
informasi pengetahuan tentang pencegahan HIV/AIDS. Diambil dari PKBI Kota Semarang sebagai pelaksana program pencegahan HIV/AIDS terdapat capaian data kelompok beresiko tinggi LSL yang tes HIV sejumlah 1.482 orang, Waria sejumlah 54 orang dan penasun sejumlah 136 dari target mulai bulan Januari sampai dengan Juni 2020. Senada dengan penelitian yang dilakukan oleh Maskuniawan (2018) menunjukkan bahwa kelompok beresiko yaitu kelompok waria melakukan tes HIV di Kota Semarang pada semester I yaitu 43 dengan target 40, semester II yaitu 56 dengan target 54, dan semester III yaitu 61 dengan target 72. Data ini menunjukkan bahwa layanan VCT yang menjangkau kelompok resiko tinggi cukup efektif dengan dibuktikannya kesadaran dalam melakukan tes dan konseling secara sukarela.

Dari beberapa pernyataan di atas diketahui bahwa pentingnya layanan informasi yang tertuang dalam VCT dalam pencegahan dan penularan HIV/AIDS. Rumusan masalah pada penelitian ini yaitu pertaman, apakah layanan informasi melalui VCT efektif dalam mencegah penularan HIV/AIDS pada kelompok beresiko tinggi? Kedua, bagaimanakah analisis bimbingan konseling Islam dalam pelaksanaan layanan informasi VCT? Penelitian ini bertujuan untuk mengetahui efektifnya layanan informasi yang diberikan pada proses VCT dalam pencegahan penularan HIV/AIDS kelompok berisiko tinggi, kemudian dianalis dengan model bimbingan dan konseling Islam.

\section{B. Metode}

Penelitian ini menggunakan metode kualitatif deskriptif dengan memaparkan model praktik konseling yang dilakukan PKBI Kota Semarang. Dengan menggunakan pendekatan berbasis Proses dan Hasil, penelitian ini mencoba memaparkan layanan informasi pada konseling HIV dan analisa bimbingan konseling Islam pada kelompok dampingan komunitas MSM (man sex man), TG (transgender), dan PWID (people who inject drugs) di PKBI Kota Semarang. Termasuk penelitian kualitatif karena bertujuan untuk menjawab pertanyaan penelitian melalui cara-cara berpikir formal dan argumentatif. Subyek penelitian ini adalah kelompok beresiko tinggi yang melakukan tes VCT yang 
Layanan Informasi melalui Voluntary Counseling ...

diadakan oleh Perkumpulan Keluarga Berencana Indonesia (PKBI) Kota Semarang. Data penelitian dikumpulkan melalui wawancara dan studi dokumentasi. Analisis data penelitian melalui tiga tahapan, yaitu reduksi data, display data, dan verifikasi data.

\section{Pembahasan}

\section{Kajian Teori}

\section{a. Layanan Informasi melalui VCT}

Proses konseling melibatkan manusia dan kemanusiaan sebagai totalitas yang menyangkut potensi dan perkembangannya, dinamika kehidupan, permasalahan dan interaksi dinamis berbagai unsur yang ada. Salah satu layanan yang terkandung dalam proses konseling adalah layanan informasi. Informasi yang disampaikan memberikan berbagai macam pengetauan, mengandung materi-materi terkait dengan tujuan tertentu.

Layanan informasi dalam VCT memiliki tujuan untuk memberikan informasi kepada klien tentang menjaga kesehatan seksual agar terhindar dari penyakit infeksi menular seksual (IMS). Selain itu, informasi dari konseling pra dan pasca VCT bertujuan untuk pemberian informasi pencegahan penularan HIV/AIDS. Prawesti mengatakan bahwa dengan melakukan VCT, klien akan mengetahui status HIV dan selama proses konseling klien mendapatkan informasi tentang cara menjaga kesehatan seksual (Prawesti et al., 2018).

VCT pada dasarnya sama dengan konseling pada umumnya. Namun konseling HIV/AIDS menjadi unik dibanding konseling lainnya karena : 1) Membutuhkan pengetahuan yang luas tentang infeksi menular seksual (IMS) dan HIV/AIDS. 2) Membutuhkan pembahasan mengenai praktik seks yang bersifat pribadi. 3) Membutuhkan pembahasan tentang kematian atau proses kematian. 4) Membutuhkan kepekaan konselor dalam menghadapi perbedaan pendapat dan nilai yang mungkin sangat bertentangan dengan nilai yang dianut oleh konselor itu sendiri. 5) Membutuhkan keterampilan pada saat memberikan hasil HIV yang positif. 6) Membutuhkan 
keterampilan dalam menghadapi kebutuhan pasangan anggota keluarga klien.

Strategi dalam VCT guna pencegahan serta sebagai jalan untuk mendapatkan layanan perawatan, dukungan dan sebagai akses obat bagi orang dengan HIV/AIDS (ODHA). Melalui VCT, klien dapat mengakses layanan medis, dukungan sosial, dan layanan konseling lanjutan jika diperlukan. Penyakit HIV/AIDS dapat mengancam kehidupan dan memerlukan pengobatan sepanjang hidupnya, sehingga dapat menimbulkan stigma di masyarakat. Dari beberapa pengertian di atas dapat diketahui bahwa layanan informasi yang ada selama proses VCT menjadi satu upaya penting untuk pencegahan HIV/AIDS sejak dini.

\section{b. Penularan HIV/AIDS pada Kelompok Resiko Tinggi}

HIV singkatan dari Human Immunodeficiency Virus yaitu sejenis virus yang menyerang system kekebalan tubuh manusia. Virus HIV akan masuk ke dalam sel darah putih dan merusaknya, sehingga sel darah putih yang berfungsi sebagai pertahanan terhadap infeksi akan menurun jumlahnya. Akibatnya sistem kekebalan tubuh menjadi lemah dan penderita mudah terkena berbagai penyakit. Kondisi ini disebut AIDS.

AIDS singkatan dari Acquired Immuno Deficiency Syndrom, yaitu kumpulan gejala penyakit (sindrom) yang didapat akibat turunnya kekebalan tubuh yang disebabkan oleh HIV. Ketika individu sudah tidak lagi memiliki sistem kekebalan tubuh, maka semua penyakit dapat masuk ke dalam tubuh dengan mudah (infeksi oportunistik). Oleh karena itu sistem kekebalan tubuhnya menjadi sangat lemah. Karenanya penyakit yang mulanya tidak berbahaya menjadi sangat berbahaya.

Mendeteksi dini status keterjangkitan virus yang ada didalam diri masing-masing yakni dengan melakukan tes VCT. Namun ada beberapa cara juga untuk pencegahan penularan virus HIV dalam Kementrian Kesehatan RI diantaranya sebagai berikut (RI, 2018). 
1) Abstinence merupakan pencegahan awal yang mendorong seseorang untuk tidak melakukan seks beresiko atau berganti-ganti pasangan.

2) Be faithful merupakan pencegahan lanjutan yang bertujuan untuk mengarahkan seseorang untuk setia dengan pasangan yang dimiliki, saling menjaga satu sama lain dan tentunya tidak berganti-gani pasangan.

3) Use condom adalah sebuah metode pencegahan dengan memakai kondom secara benar. Tahap ini dilakukan hanya jika setelah pencegahan pertama dan kedua gagal. Tahapan ini merupakan tahapan yang masih sangat efektif digunakan oleh seseorang atau pun kelompok yang melakukan seks beresiko.

4) Drugs merupakan anjuran untuk tidak menggunakan narkoba dan zat adiktif lainnya. Media penularan yang paling berbahaya adalah bergantian alat suntik yang tidak steril, alat tindik atau alat tato. Hanya dengan menghindari penggunaan narkoba, kita sudah memberikan perilaku pencegahan dalam penularan virus HIV.

5) Education adalah sebuah cara yang dilakukan secara terus menerus hingga saat ini yakni membekali diri dengan informasi mengenai HIV AIDS dari layanan kesehatan. Berusaha menjadi teman sebaya bagi seseorang terdekat atau keluarga untuk membagi informasi yang kita ketahui mengenai HIV AIDS agar tidak muncul stigma berlebih pada masyarakat umum.

HIV dan virus-virus sejenisnya umumnya ditularkan melalui kontak langsung antara lapisan kulit dalam atau aliran darah, dengan cairan tubuh yang mengandung HIV bisa menular melalui cairan sperma, darah dan air susu ibu (ASI). Perilaku yang sering ditemui pada masyarakat yakni melakukan pasangan multi-partner seks yang beresiko baik sesama jenis ataupun lawan jenis tanpa menggunakan pengaman (kondom) dan menggunakan narkoba terutama narkoba jenis suntik secara bergantian. Upaya pencegahan harus serius dilakukan untuk segera menemukan 
seseorang yang teinfeksi virus HIV karena hanya dengan tes HIV, seseorang mampu mengetahui status positif dan negatif HIV/AIDS. Dari pernyataan ini diketahui bahwa pasanganmulti-partner, pengguna narkoba suntik menjadi salah satu kelompok resiko tinggi terinfeksi virus HIV/AIDS, maka dirasa penting untuk melakukan pencegahan penularan HIV/AIDS untuk kelompok resiko tinggi.

\section{Hasil dan Analisis Penelitian}

\section{a. Layanan Informasi melalui VCT dalam Pencegahan Penularan HIV/AIDS}

Pengguna narkoba suntik (Penasun)/People Who Inject Drug (PWID), pekerja seks dan pelanggan mereka, lelaki yang berhubungan seks dengan lelaki, narapidana, pelaut, dan pekerja di sektor transportasi lebih berisiko terkena infeksi HIV. Mobilitasi dan migrasi pun berperan dalam meningkatnya penularan HIV. Banyak kelompok risiko tinggi tidak dapat mengakses pelayanan utama HIV/AIDS, karenanya program penjangkauan dan jaringan kelompok sebaya (peer network) harus dapat membawa kelompok ini ke tempat-tempat pelayanan tersebut. Pemerintah dan KPA (Komisi Penanggulangan AIDS), dengan dukungan donor internasional, saat ini aktif mengembangkan kebijakan HIV/AIDS dan program-program lokal. Sumbangan berupa pelatihan manajemen organisasi, termasuk perencanaan strategis dan pendanaan program, dapat membantu KPAD (Komisi Penanggulangan AIDS Daerah) di tingkat provinsi dan daerah, serta berbagai LSM terkait dalam melaksanakan tugas mereka.

HIV/AIDS merupakan penyakit yang belum ditemukan vaksin atau obat yang efektif untuk menyembuhkan secara total hingga saat ini. Secara global ada sebanyak 36 juta orang dengan HIV/AIDS di penjuru dunia, di Asia Selatan dan Tenggara sekitar 5 juta orang dengan HIV. Epidemi HIV/AIDS di Indonesia bertumbuh paling cepat di antara negara-negara di Asia dengan estimasi peningkatan angka kejadian infeksi HIV lebih dari 36\%. (UNAIDS, 2014). 
Kelompok beresiko yang kami maksud cakupannya meliputi men sex men (MSM) atau Gay, Waria dan PWID dampingan rujukan tes HIV dari PKBI Kota Semarang. Mereka menjadi populasi kunci dalam kasus persebaran HIV/AIDS karena masih kurangnya kesadaran secara pribadi terkait kesehatan seksual. Pendampingan terhadap kelompok beresiko sangat perlu dalam penyampaian informasi pengetahuan tentang pencegahan HIV/AIDS. Diambil dari PKBI Kota Semarang sebagai pelaksana program pencegahan HIV/AIDS terdapat capaian data kelompok beresiko tinggi LSL yang tes HIV sejumlah 1.482 orang, Waria sejumlah 54 orang dan penasun sejumlah 136 dari target mulai bulan Januari sampai dengan Juni 2020.

Kelompok resiko tinggi pada telah menyadari bahwa memiliki perilaku yang dapat menyebabkan tertularnya HIV/AIDS, walaupun kerap kali mereka merasa ragu untuk mengikuti program VCT. Perkumpulan Keluarga Berencana Indonesia (PKBI) Kota Semarang memiliki progam dalam pendamping pencegahan HIV/AIDS. Tim petugas lapangan (PL) bertugas untuk menjangkau komunitas populasi kunci yaitu MSM, TG, dan PWID yang sebelumnya belum terlayani atau belum dijangkau.

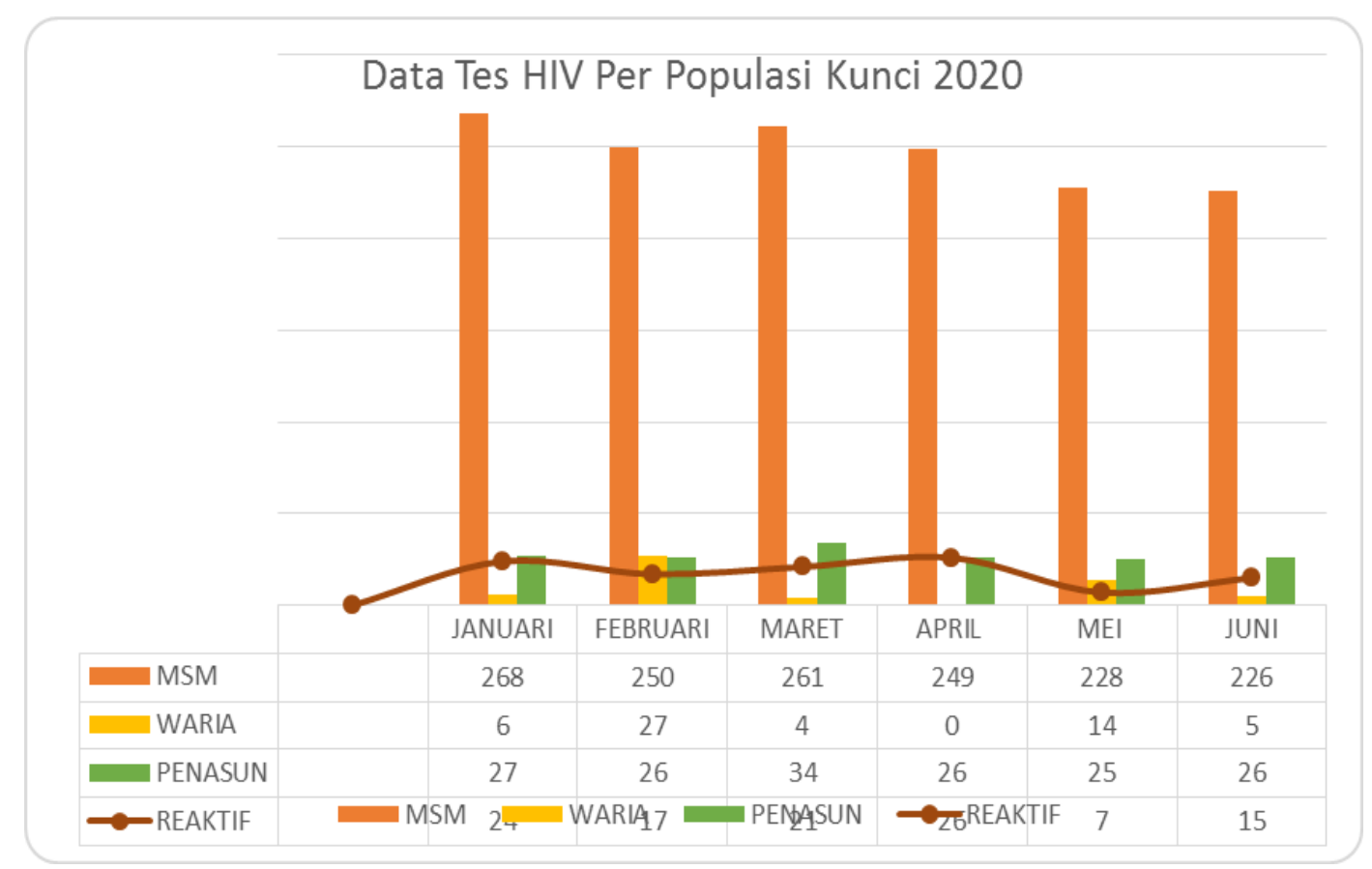


Gambar 1. Data tes HIV Populasi Kunci (MSM, TG, dan PWID) di PKBI Kota Semarang.

Berdasarkan diagram tersebut, menunjukkan jumlah kelompok resiko tinggi yang melakukan VCT dari bulan Januari sampai bulan Juni 2020. Hasil menunjukkan pada kelompok MSM cukup banyak yang sudah terjangkau dengan angka paling sedikit 226 sampai 268 orang. Pada kelompok waria paling banyak 27 orang, sedangkan pada kelompok PWID angka tertinggi sebanyak 34 dan paling sedikit 26 orang. Dari gambar di atas juga diketahui bahwa setiap bulan terdapat klien yang berstatus reaktif atau postif HIV. Jumlah klien yang reaktif setiap bulannya cukup beragam gabungan dari beberapa populasi kelompok beresiko. Dari data ini dapat diketahui bahwa kelompok beresiko tinggi sudah memiliki kesadaran bahwa tes VCT penting dalam mengetahui status HIV nya.

Layanan VCT merupakan bentuk wawancara yang sifatnya rahasia dengan tujuan untuk membuat klien dapat menyesuaikan diri dan mampu membuat keputusan terkait HIV/AIDS. Proses konseling ini juga sebagai evaluasi terhadap resiko penularan HIV dan evaluasi diri ketika klien menghadapi hasil tes HIV positif. Layanan VCT adalah suatu pembinaan dua arah atau dialog yang berlangsung tak terputus antara konselor dan klien dengan tujuan untuk mencegah penularan HIV, memberikan dukungan moral, informasi, serta dukungan lainnya kepada ODHA, keluarga dan lingkungannya. Jadi VCT memberikan konseling secara menyeluruh yaitu dari awal pra test, pasca tes dan konseling berkelanjutan bagi klien agar mampu beradaptasi dengan penyakitnya bahkan memfasilitasi konseling antara klien dan keluarganya.

Konseling yang diberikan harapannya mampu memberikan dukungan psikologis seperti dukungan kesejahteraan emosi, sosial, dan spiritual orang dengan HIV/AIDS, menyediakan informasi tentang perilaku beresiko, membantu klien mengembangkan ketrampilan pribadi dalam menghadapi penyakit, dan mendorong klien untuk rutin mengakses pengobatan. Dengan 
demikian semakin jelas bahwa VCT berusaha memberikan bantuan dan memfasilitasi kebutuhan penderita HIV/AIDS ataupun masyarakat dalam upaya pencegahan dan penanggulangan penyakit ini. Arah konseling bagi penderita HIV/AIDS adalah memberikan beragam dukungan yang dibutuhkan dalam menghadapi penyakitnya. Jadi dapat disimpulkan bahwa konseling HIV/AIDS dilakukan secara khusus bagi kelompok-kelompok beresiko HIV/AIDS agar mereka memahami kemungkinan penularannya dan mendapatkan dukungan jika dinyatakan postif HIV/AIDS.

Petugas lapangan PKBI kota semarang merujuk klien dampingan ke puskesmas untuk tes VCT. Sistem layanan VCT bisa berjalan dengan baik karena terpenuhinya beberapa hal yaitu pelaku pendampingan kelompok resiko tinggi dalam mengakses VCT, sebagai berikut.

1) Konselor

PKBI Kota Semarang memiliki dua konselor yang sudah menempuh pendidikan dan pelatian konselor HIVAIDS. Konselor HIV pada pada dasarnya memiliki tugas yang sama dengan konselor pada umumnya, yaitu untuk membantu klien memandirikan dirinya. Namun, perbedaannya adalah konselor HIV dituntut untuk memiliki pengetahuan dan pemahaman akan kesehatan reproduksi, penyakit HIV/AIDS, baik penularan, pencegahan dan perawatannya.

Seseorang hanya dapat mengetahui terinfeksi HIV atau tidak, melalui pemeriksaan darahnya. Kelompok beresiko dianjurkan untuk tes VCT secara berulang setiap 3 bulan sekali. Tujuan utama tes HIV dengan segera yaitu agar dapat mengetahui status HIV nya, sehingga segera dapat pelayanan selanjutnya yang dibutuhkan, seperti rencana pengobatan dan bagaimana langkah pencegahan penularan. Adapun tahapan konseling tes HIV sebagai berikut.

a) Konseling Pra-tes

Tes HIV hanya dapat dilakukan dengan menemui dokter, konselor terlatih, perawat, atau petugas kesehatan. Pada tahap ini 
seorang konselor memberikan penjelasan mengenai informasi HIV/AIDS, apa yang akan dilakukan pada saat tes dan bagaimana jika hasilnya positif.

b) Tes HIV

Tahap tes HIV dilakukan hanya ketika klien menyetujuinya, tanpa paksaan dan secara sukarela. Pada tahap ini petugas laboratorium akan mengambil sedikit darah untuk diperiksa.

c) Konseling Pasca-tes

Konselor pada tahap ini konselor menyampaikan hasil pemeriksaan darah. Hasil tes darah bersifat rahasia, hanya dokter atau konselor yang mengetahui hasil pemeriksaan. Kemudian jika hasilnya reaktif atau positif maka akan diberikan pendampingan, memutuskan rencana pengobatan. Biasanya tahap ini klien akan diberi pilihan dalam untuk mendapat pendampingan dari konselor, peer support atau mandiri.

2) Petugas Lapangan (PL)

Petugas lapangan memiliki tugas untuk MENGINFORMASIKAN tentang HIV/AIDS kepada komunitas kelompok resiko tinggi, memberikan informasi layanan VCT dan merujuk damping untuk tes ke puskesmas. Selain itu, PL juga memastikan klien dampingan yang dinyatakan positif untuk mendapatkan akses pengobatan.

3) Peer Support

Dukungan bagi mereka yang terinfeksi HIV sangat berarti. Peer support atau pendamping sebaya memiliki tugas untuk mendampingi orang dengan HIV/AIDS (ODHA). Pendamping sebaya memberikan dukungan berupa informasi pengetahuan tentang sakitnya, dukungan sosial, dan pendampingan untuk mengakses obat.

Dari pernyataan di atas dapat dipahami bahwa informasi mengenai semua hal tentang HIV/AIDS baik penularan, pencegahan dan pengobatan sangat penting untuk disampaikan dalam sesi konseling HIV. Layanan 
informasi dalam konseling diartikan sebagai layanan yang memberikan data atau informasi guna memberikan pemahaman baru yang dibutuhkan individu (Nurihsan, 2014). Sebagai bentuk perwujudan fungsi pemahaman dalam konseling, layanan informasi berfungsi untuk membantu individu menyelesaikan masalahnya, membekali diri dengan berbagai pengetauan dan pemahaman yang dituang dalam kehidupan sehari-hari.

b. Analisis Bimbingan Konseling Islam dalam Pelaksanaan Layanan Informasi melalui VCT di pkbi kota Semarang

Informasi yang disampaikan dalam proses konseling HIV di PKBI menjadi bagian dari layanan informasi yang bertujuan untuk memahamkan, memberikan informasi yang dibutuhkan oleh klien. Konseling yang dikembangkan adalah konseling pencegahan HIV/AIDS. Kemudian arti bimbingan merupakan proses pemberian bantuan kepada individu agar mampu memahami diri, lingkungan dan memiliki tujuan hidup. Bimbingan dalam kamus Besar Bahasa Indonesia memiliki makna sebagai petunjuk, pemberi jalan, dan menuntun individu kearah yang lebih baik dari sebelumnya (Hidayanti, 2015). Layanan bimbingan diberikan kepada individu untuk memberikan pemahaman, dan pengetahuan yang diperlukan individu. Penggunaan ajaran agama dapat menjadi salah satu alternatif yang dapat dilakukan pembimbing dalam pengubahan tingkah laku individu.

Bimbingan dan konseling Islam (BKI) merupakan pemberian bantuan yang didasarkan pada aturan atau norma-norma yang berlaku (Tohirin, 2014). Bantuan yang diberikan berbentuk pemberian dorongan dan pendampinga untuk menjadi lebih baik. Sutoyo menyatakan bahwa bimbingan konseling Islam adalah upaya membantu individu untuk belajar mengembangkan fitrah dengan memberdayakan iman, akal, dan kemauan dikaruniakan Allah SWT (Sutoyo., 2019). Dari rumusan tersebut tampak, bahwa konseling Islam adalah aktifitas yang bersifat "membantu", dikatakan membantu karena pada hakekatnya individu sendirilah yang perlu hidup sesuai tuntutan Allah (jalan yang lurus) agar mereka selamat. 
Karena posisi konselor bersifat membantu, maka konsekuensinya individu sendiri yang harus aktif belajar memahami dan sekaligus melaksanakan tuntutan Islam (al-Qur"an dan sunah rasul-Nya) (Bastomi \& Aji, 2018). Pada akhirnya tugas akhir bimbingan konseling Islam yaitu membawa individu untuk bahagia dunia dan akhirat.

Sedangkan tujuan bimbingan dan konseling Islam menurut Mubarok dalam Bastomi (2017) Secara singkat dapat dirumuskan sebagai berikut : (1) Tujuan umum Konseling Islam untuk membantu konseli agar dia memiliki pengetahuan tentang posisi dirinya dan memiliki keberanian mengambil keputusan, untuk melakukan suatu perbuatan yang dipandang baik, benar dan bermanfaat, untuk kehidupannya di dunia dan untuk kepentingan akhiratnya. (2) Tujuan khusus bimbingan konseling Islam adalah: (a) Untuk membantu konseli agar tidak menghadapi masalah. (b) Untuk membantu konseli mengatasi masalah yang sedang dihadapinya. (c) Untuk membantu konseli memelihara dan mengembangkan situasi dan kondisi yang baik atau yang telah baik agar tetap baik, sehingga tidak akan menjadi sumber masalah bagi dirinya dan orang lain. Guna mencapai tujuan bimbingan konseling sesuai yang diharapkan tentunya proses manajemen bimbingan dan konseling harus berjalan dengan sangat baik.

Fungsi bimbingan konseling Islam yaitu sebagai fasilitator dan motivator untuk membantu klien memecahkan permasalahannya.Konseling yang dimaksud yaitu untuk membantu individu agar mampu membangun kehidupan mereka secara menyeluruh. Senada dengan pendapat konselor PKBI Kota Semarang, Ruben (konselor VCT) mengatakan bahwa konselor mempunyai tugas dalam pendampingan untuk memfasilitasi, mengajarkan dan mendukung klien (wawancara, 7 September 2020). Sebagaimana pendapat Yusuf dan Nurihsan dalam Hidayanti bimbingan sebagai upaya untuk menciptakan lingkungan (fisik, psikis, sosial dan spiritual) yang kondusif bagi perkembangan klien (Hidayanti, 2019). Mengacu pendapat 
dari konselor VCT di PKBI Kota Semarang sudah kental dengan nuansa bimbingan dan pendampingan.

Bimbingan konseling Islami sebagai upaya memelihara fitrah (potensi) yang dimaksud adalah pemberdayaan iman, pikiran dan keinginan tentang belajar kebutuhan. Upaya ini dilakukan dengan cara memberdayakan (enpowering) iman, akal, dan kemauan yang dikaruniakan Allah SWT kepada para klien. Hal ini agar fitrah yang ada pada individu dapat berkembang dengan benar dan kokoh sesuai tuntunan-Nya. Sehingga klien yang melakukan proses VCT kembali mendapatkan pedoman, dapat berperilaku lebih sehat, dan dukungan yang maksimal.

Kegiatan utama yang harus dilakukan adala membantu klien dalam mengembangkan fitrah yaitu dengan dorongan dan membantu memahami ajaran agamanya. Dengan memahamai syariat agama dengan benar, maka diharapkan fitrah iman individu dapat berkembang dengan optimal. Sehingga pada akhirnya dengan matangnya fitrah iman bisa berfungsi sebagai pendorong, pemberi arah terhadap klien VCT.

Hal terpenting yang harus dipahami oleh konselor maupun klien adalah, bahwa dalam bimbingan dan konseling Islami tugas konselor hanyalah membantu. Klien sendiri yang harus berupaya untuk hidup sesuai dengan tuntunan Islam. Begitu pula dalam pelaksaan VCT, konselor mempunyai wewenang untuk memberikan pendampingan. Tetapi klien lebih mempunyai hak untuk melakukan tindak lanjut terhadap keputusannya.

Selanjutnya, dalam pelaksanaan pengembangan fitrah manusia ada beberapa layanan dalam bimbingan konseling Islam yang dapat dilakukan antara lain layanan informasi agama. Jenis layanan infomasi ini memungkinkan klien yang beragama menerima dan memahami informasi keberagamaannya dari sumber yang layak dipercaya. Langkah ini agar dapat digunakan sebagai bahan pertimbangan dalam melakukan amal-amal keagamaan dalam mengambil keputusan dan pertimbangan bagi penentuan 
sikap dan tingkah laku keberagamaan. Layanan informasi agama bertujuan membekali klien VCT dengan berbagai hal yang sangat berguna bagi kehidupan.

\section{Simpulan}

Berdasarkan temuan dan analisis penelitian ini dapat disimpulkan bahwa layanan informasi melalui VCT dalam pencegahan dan penularan HIV/AIDS pada kelompok resiko tinggi cukup efektif. Dari hasil analisis sudah sesuai dengan fungsi bimbingan dan konseling Islam yaitu membantu klien untuk memelihara fitrah dan memandirikan klien.

Dari penelitian ini patut dipertimbangkan bagi konselor VCT, Kelompok beresiko untuk dapat menerapkan beberapa pendekatan konseling, salah satunya yaitu bimbingan konseling Islam. Bagi peneliti selanjutnya dapat mempertimbangkan variabel lain untuk treatment dalam layanan VCT, misalnya menggunakan pendekatan realita, person centered, CBT, eksistensial humanistik atau pendekatan konseling lainnya. 


\section{DAFTAR PUSTAKA}

Bastomi, H. (2017). Menuju Bimbingan Konseling Islami. KONSELING EDUKASI: Journal Of Guidance And Counseling, 1 No. 1. https://doi.org/10.21043/konseling.v1i1.4434

Bastomi, H., \& Aji, M. A. S. (2018). Konseling Rational Emotif Behaviour Theraphy (Rebt)-Islami (Sebuah Pendekatan Integrasi Keilmuan). KONSELING EDUKASI : Journal of Guidance And Counseling, 2, No 2, 25-45. https://doi.org/10.21043/konseling.v2i2.4465

Hidayanti, Ema. (2012). Dimensi Psiko-spiritual dalam Praktik Konseling bagi Penderita HIV/AIDS di Klinik VCT Rumah Sakit Panti Wiloso Citarum Semarang.

Marlinda, Yetik. Azinar, Muhammad. (2017). Perilaku Pencegahan Penularan HIV/AIDS. Jurnal Ilmu Kesehatan Masyatakat UNNES.

Maskuniawan,. \& Azinar, M. (2018). Faktor-faktor yang Berhubungan dengan Praktik Tes HIV pada Waria Pekerja Seks di Kota Semarang. Journal of Health 3 (1).

Hidayanti, E. (2015). Dasar-Dasar Bimbingan Rohani Pasien. Karya Abadi Jaya.

Hidayanti, E. (2019). Implementasi Bimbingan Dan Konseling Untuk Meningkatkan Self Esteem Pasien Penyakit Terminal Di Kelompok Dukungan Sebaya (KDS) Rsup Dr. Kariadi Semarang. Jurnal Ilmu Dakwah, 38(1), 31. https://doi.org/10.21580/jid.v38.1.3970

Nurihsan, A. J. (2014). Bimbingan dan Konseling Dalam Berbagai Latar Kehidupan. PT Refika Aditama.

Prawesti, N. A., Purwaningsih, \& Armini, N. K. A. (2018). Faktor Pendorong Pemanfaatan Layanan Voluntary Counselling and Testing (VCT) oleh Lelaki Suka dengan Lelaki (LSL) di LSM Gaya Nusantara. Jurnal Ners Dan Kebidanan, 5(2). https://doi.org/10.26699/jnk.v5i2.ART.p129-136

Retnaningsih, D. A. S. (2016). Voluntary Counseling and Testing untuk Orang Beresiko HIV/AIDS. Jurnal Dakwah Dan Komunikasi, 1(1). 
https://doi.org/10.22515/balagh.v1i1.61

RI, K. K. (2018). Buku Saku HIV AIDS dan IMS.

Satriani, S., Nurhayani, N., \& Balqis, B. (2016). STUDI MUTU PELAYANAN VOLUNTARY COUNSELING AND TESTING (VCT) DI PUSKESMAS JONGAYA MAKASSAR. Media Kesehatan Masyarakat Indonesia, 9(4), 243-249. https://journal.unhas.ac.id/index.php/mkmi/article/view/462

Sumini,. Hadisaputro, S. dkk. (2017). Faktor Risiko yang Berpengaruh terhadap Kejadian HIV/AIDS pada Pengguna Napza Suntik (Studi Epidemiologi Di Kota Pontianak). Jurnal Epidemiologi Kesehatan Komunitas, 2(1), 36-45. https://doi.org/https://doi.org/10.14710/jekk.v2i1.3993

Sutoyo., A. (2019). Bimbingan \& Konseling Islami (Teori dan Praktik). Pustaka Pelajar.

Tohirin. (2014). Bimbingan dan Konseling di Sekolah dan Madrasah (Berbasis Integrasi). PT Raja Grafindo Persada.

UNAIDS. (2014). UNAIDS Scientific Expert Panel 2013-2015. UNAIDS. 